\title{
ПРОБЛЕМИ УДОСКОНАЛЕННЯ ЕКСТРЕНОЇ МЕДИЧНОЇ ДОПОМОГИ НА РІЗНИХ ЕТАПАХ ЇÏ НАДАННЯ ЧЕРЕЗ ПРИЗМУ МЕДИЧНОЇ РЕФОРМИ
}

\author{
Т. В. Коса ${ }^{1}$, О. Н. Литвинова ${ }^{2}$ \\ ${ }^{1}$ Комунальна установа «Запорізька станиія екстреної (ивидкої) \\ медичної допомоги" Запорізької обласної ради \\ ${ }^{2}$ Тернопільський національний медичний університет \\ імені І. Я. Горбачевського МОЗ Украӥни
}

\begin{abstract}
У статті висвітлено проблеми потреб врегулювання організації та функціонування служби екстреної медичної допомоги на різних рівнях догоспітального етапу. Запропоновано акцентувати увагу на системному підході до організації екстреної медичної допомоги.
\end{abstract}

\section{PROBLEMS OF IMPROVEMENT OF EMERGENCY MEDICAL CARE AT DIFFERENT STAGES OF ITS PROVISION THROUGH THE PRISM OF MEDICAL REFORM}

\author{
T. V. Kosa ${ }^{1}$, O. N. Lytvynova ${ }^{2}$ \\ ${ }^{1}$ Zaporizhzhia Regional Emergency and Disaster Medicine Center \\ ${ }^{2}$ I. Horbachevsky Ternopil National Medical University
}

\begin{abstract}
The article highlights the problems of the needs of regulation of the organization and functioning of the emergency medical service at different levels of the pre-hospital stage. It is proposed to focus on a systematic approach to the organization of emergency medical care.
\end{abstract}

Вступ. Тактика медичної реформи в Україні 2018 р. полягала у триетапній трансформації системи охорони здоров'я. На першому етапі відбулося реформування первинної ланки надання медичної допомоги, що включало не лише сімейну медицину, а й екстрену та невідкладну медичну допомогу. Наступні етапи передбачали реформування вторинної, третинної медичної допомоги та запровадження професійного ліцензування лікарів.

Метою медичної реформи було трансформування сфери охорони здоров'я для підвищення якості медичних послуг, доступності ліків, поліпшення ефективності використання бюджетних коштів, долучення місцевого самоврядування до розвитку медичної галузі, підвищення рівня задоволеності населення системою охорони здоров'я, зміцнення здоров'я та подовження тривалості життя громадян.

як елемент реформування, Уряд вніс зміни до Типового положення про бригаду екстреної (швидкої) медичної допомоги, що передбачено Постановою Ка-

(c) Т. В. Коса, О. Н. Литвинова, 2020 бінету Міністрів України від 21 серпня 2019 р. № 764. Відтепер функціонуватимуть бригади екстреної медичної допомоги, до складу яких входитимуть парамедики та екстрені медичні техніки, що передбачало поліпшити своєчасність та якість надання екстреної медичної допомоги, знизити рівень смертності від нещасних випадків, травм та гострих захворювань [1].

Актуальність даного питання спонукала нас на дослідження шляхів удосконалення екстреної медичної допомоги на різних етапах ії надання через призму медичної реформи на прикладі Запорізької області.

Основна частина. Запорізька область має велику протяжність території, розгалужену мережу населених пунктів та всього п'ять територіальних округів та декілька лікарень, які можуть приймати хворих та постраждалих цілодобово.

Першою проблемою реалізації положень медичної реформи є стан наших доріг, які не дають можливості бригадам екстреної медичної допомоги швидко та без перешкод доставляти хворих до лікувальних закладів, вкладаючись в так зване «терапевтичне вікно» 
при інсультах, гострому коронарному синдромі, інфаркті міокарда чи політравмі.

Дещо згладжує ситуацію той факт, що у місті Запоріжжя працює оперативно-диспетчерське управління на базі Комунального некомерційного підприємства «Територіальне медичне об'єднання «Обласний центр екстреної медичної допомоги та медицини катастроф» Запорізької обласної ради, яке приймає виклики від громадян та від працівників медичних закладів за телефонною лінією «103». Потім, фельдшер із медицини невідкладних станів з приймання викликів та передачі їх виїзним бригадам швидкої медичної допомоги (ШМд) передає виклик в електронному вигляді на смартфон або планшет виїзним бригадам ШМД, що значно скорочує час прийняття виклику та його передачу, це суттєво впливає на доїзд бригади до місця виклику. За статистичними даними: доїзд бригад екстреної (швидкої) медичної допомоги у містах області складає $89 \%$ до 10 хв, а у сільській місцевості - 88 \% до 20 хв.

Шанси на те, що у разі настання нещасного випадку чи серцевого нападу життя людини буде врятоване, а негативні наслідки для здоров'я - мінімізовані, залежать від строку початку надання першої допомоги та строку початку проведення критичних для виживання процедур на догоспітальному етапі, які повинні бути мінімальними. Не менше значення має ефективне госпітальне лікування та реабілітація.

У практичній медицині на кожному вказаному етапі $є$ певні проблеми.

Як ми уже показали на прикладі м. Запоріжжя, перша проблема це недосконала організація раннього доступу до надання першої допомоги, що лише незначною мірою залежить від працівників екстреної медичної допомоги. якість доріг, їх завантаженість, культура дорожнього руху, справність та кількість медичного транспорту, відсутність назв вулиць та нумерації будинків тощо - це ті причини, які подовжують термін надання невідкладної допомоги, а згідно з доказовими дослідженнями [2], статистично значуще зростання показників виживання серед пацієнтів екстреної медичної допомоги досягається лише у разі, коли пацієнти можуть розраховувати на початок такої допомоги не пізніше ніж через 4 хв після настання екстреної ситуації. Настільки ранній доступ можливий лише у разі надання ефективної першої допомоги та забезпечення базової підтримки життя безпосередніми свідками на місці події. Хоча такі особи не можуть замінити професійних медич- них працівників, вони можуть допомогти підтримати життя до прибуття професіоналів.

В Україні навички першої допомоги формально $\epsilon$ частиною підготовки деяких фахівців (рятувальників аварійно-рятувальних служб, поліцейських тощо). Проте поточний підхід до їх залучення не $\epsilon$ ефективним через ряд причин:

- не існує ефективного механізму контролю якості знань за результатами освітніх заходів;

- не існує реєстру осіб, які пройшли тренінги 3 надання першої допомоги, та відсутній механізм оперативного залучення їх до надання першої допомоги у разі настання нещасного випадку або надзвичайної ситуації;

- добровольці, які наважуються рятувати людину до прибуття швидкої, ніяк не захищені законодавством від притягнення до відповідальності у разі, коли людині все-таки не вдасться зберегти життя [2].

У порядку законодавчої ініціативи у Верховній Раді України зареєстровано проект Закону України «Про внесення змін до деяких законів України щодо удосконалення надання першої допомоги» [3].

У результаті прийняття цього Закону громадяни України, іноземці та особи без громадянства, які перебувають на території України, в разі необхідності екстреної медичної допомоги отримають реальний шанс на виживання завдяки додатковій законодавчій мотивації пересічних громадян, які зможуть надати першу допомогу без страху подальшого покарання.

Ще однією проблемою екстреної допомоги $\epsilon$ те, що певна кількість громадян України, зокрема особи з вадами зору та слуху, самостійно позбавлена шансу викликати екстрену медичну допомогу, оскільки такий виклик може прийматися лише через телефонний дзвінок.

Багато свідчень сьогодні $\epsilon$ щодо незадовільної якості надання медичної допомоги на догоспітальному етапі [2].

Професійна підготовка, кваліфікаційні вимоги та організація діяльності медичних працівників системи екстреної медичної допомоги часто не включає навичок роботи в команді. Водночас саме ефективна командна робота $є$ запорукою якісної медичної допомоги пацієнту, який перебуває у невідкладному стані. Результати досліджень свідчать, що часто причиною смерті або ускладненого перебігу захворювання пацієнтів, які перебувають у невідкладному стані, $\epsilon$ не лише індивідуальні помилки окремих медичних працівників, але і неефективність координації ко- 
мандної роботи фахівців бригади екстреної (швидкої) медичної допомоги або працівників відділення екстреної (невідкладної) медичної допомоги закладу охорони здоров'я.

Низький рівень набутих навичок медичних працівників системи екстреної медичної допомоги зумовлений як відсутністю ефективних принципів підготовки фахівців, так і відсутністю ефективної системи контролю якості знань. Індивідуальна оцінка готовності лікарів до виконання своїх обов'язків сьогодні обмежується системою атестації та переатестації для підтвердження або підвищення кваліфікації. Цей підхід має ряд недоліків, а саме:

- формальний характер, відсутність нагляду за якістю курсів підвищення кваліфікації та незалежного оцінювання для перевірки їх результатів, що створює корупційні ризики (адже якість навчання перевіряє та ж організація, що проводить це навчання);

- відсутність засвоєння та відновлення практичних навичок під час підвищення кваліфікації;

- застарілі програми, далекі від щоденної практики бригади екстреної (швидкої) медичної допомоги;

- відсутність ефективного механізму нагляду за проведенням передатестаційних циклів;

- відсутність дієвого механізму офіційного визнання міжнародних курсів, які проходять працівники системи екстреної медичної допомоги, як курсів, що зараховуються під час підвищення кваліфікації, що демотивує працівників опановувати доказові міжнародні практики.

Окремою додатковою проблемою $\epsilon$ відсутність в Україні національних галузевих стандартів у сфері охорони здоров'я з надання екстреної медичної допомоги, що ґрунтуються на доказовій медицині. Наявні галузеві стандарти часто суперечать доказовим міжнародним практикам. Також відсутній і механізм нагляду за дотриманням галузевих стандартів у сфері охорони здоров'я з надання екстреної медичної допомоги медичними працівниками.

У Концепції зазначається ще одна проблема - незадовільна якість та швидкість надання екстреної медичної допомоги на госпітальному етапі [2].

Шанси пацієнта не лише своєчасно потрапити в лікарню, але і бути успішно пролікованим, прямо залежать від підходів до організації надання екстреної медичної допомоги на госпітальному етапі. Ймовірність летального випадку, в тому числі через додаткові ускладнення, сьогодні збільшують такі чинники:
- невідповідність сучасним вимогам надання екстреної медичної допомоги у відділеннях екстреної (невідкладної) медичної допомоги закладів охорони здоров'я, що приймають пацієнтів;

- неспроможність більшості закладів охорони здоров'я, куди доставляють пацієнтів, провести повноцінну діагностику і надати комплексну медичну допомогу хворому, який перебуває у невідкладному стані;

- транспортування хворих, які перебувають у невідкладному стані, за територіальним принципом;

- відсутність чітких моделей комунікації та координації між бригадою екстреної (швидкої) медичної допомоги та відділенням екстреної (невідкладної) медичної допомоги;

- відсутність чітких моделей координації між відділеннями лікарні під час роботи із складними невідкладними випадками.

Крім безпосереднього впливу на перебіг захворювання та невідкладного стану пацієнта, нескоординовані процеси на рівні лікарні призводять до неефективного використання ліжкового фонду та робочого часу медичних працівників.

Для м. Запоріжжя характерна також проблема, зазначена в Концепції, - це низька спроможність системи екстреної медичної допомоги своєчасно забезпечити достатній об'єм якісної медичної допомоги у разі виникнення надзвичайних ситуацій та ліквідації їх наслідків [2].

Наявні в Україні алгоритми реагування на надзвичайні ситуації (в тому числі - плани реагування державного, регіонального рівнів та плани реагування на рівні закладів охорони здоров'я) мають ряд прогалин.

Поточні плани реагування не відстежують і не враховують реальну інформацію про здатність закладів охорони здоров'я швидко збільшити кількість лікарняних ліжок та кількість пацієнтів, які отримують екстрену медичну допомогу на госпітальному етапі. Така здатність включає не лише наявність місця для розміщення пацієнтів, але і необхідне технічне оснащення для одночасного надання екстреної медичної допомоги значній кількості осіб. Не сформована дієва система резервування медикаментів, медичних виробів. Ці недоліки особливо гостро себе проявили по всій Україні в час пандемії Covid-19. Механізм міжвідомчої координації та взаємодії під час реагування на масові випадки, в тому числі на догоспітальному етапі, також є мало дієвими. 
Найважливішими елементами системи, яка включає засоби, процеси, заходи, які залучаються до ліквідації наслідків надзвичайних ситуацій, - оперативно-диспетчерські служби - не завжди обладнані автономним радіозв'язком, що повинен об'єднувати всі наявні бригади екстреної (швидкої) медичної допомоги, підрозділи екстреної медичної допомоги та заклади охорони здоров'я [4].

Лише в поодиноких випадках працює система безперервного професійного розвитку, в тому числі практичних тренінгів щодо дій у разі виникнення інцидентів з великою кількістю постраждалих, із кризового менеджменту для працівників закладів охорони здоров'я, які працюють в режимі надання екстреної медичної допомоги.

Сучасний підхід до кадрового забезпечення системи екстреної медичної допомоги потребує удосконалення. Зокрема, повинно бути чітко визначено склад загальнопрофільних або спеціалізованих бригад. А це, відповідно, потребує введення змін та доповнень до кваліфікаційних вимог спеціалістів та фахівців, які працюватимуть у складі цих бригад. Важливою є участь водія санітарного автотранспорту в наданні медичної допомоги на догоспітальному етапі у складі єдиної бригади, а для цього необхідно провести підготовку та навчання водіїв з питань надання першої медичної допомоги, визначити обсяг їх обов'язків, що частково вирішить запровадження посади водія-парамедика.

Крім того, необхідно запровадити більш системний підхід до організації першої допомоги.

Координатором проектів ОБСє в Україні обґрунтовано необхідність системної співпраці органів державної влади та органів місцевого самоврядування, урядових та неурядових установ та організацій і громадян з метою посилення якості першої допомоги буде спрямована на виконання таких завдань [5]:

- обов'язкове оволодіння практичними навичками з надання першої допомоги та відповідна сертифікація працівників, чия діяльність пов'язана з високою ймовірністю присутності в екстрених ситуаціях і входить до їхніх обов'язків згідно із законодавством, створення і ведення реєстру таких осіб, забезпечення проведення регулярних навчань для підтримки навичок та продовження дії сертифіката, перевірок на володіння відповідними компетентностями;
- підтримка можливостей проходження бажаючими громадянами за власні кошти навчання з отриманням сертифіката екстреного медичного реагувальника або навчання загальним навичкам першої допомоги без отримання такого сертифіката;

- започаткування проведення постійної просвітницької роботи серед населення, в тому числі поширення інформації про перші кроки для свідків невідкладного стану, із залученням органів місцевого самоврядування, каналів поширення масової інформації, громадських організацій;

- розширення доступу до якісного стандартизованого навчання навичкам першої допомоги дітям для батьків під час вагітності та в післяпологовий період;

- залучення благодійних організацій та приватних підприємств на засадах корпоративної соціальної відповідальності до фінансової підтримки оснащення засобами першої допомоги місць високої ймовірності екстрених ситуацій з потребою у наданні першої допомоги постраждалим (зокрема - великих станцій громадського транспорту), розроблення інтерактивних карт та програмного забезпечення (прикладних програм для мобільних засобів комунікації) для ідентифікації розміщення найближчого оснащення першої допомоги, зокрема дефібриляторів;

- захист надавачів першої допомоги від судових переслідувань зі сторони постраждалого або його законних представників у разі, коли вони допустили помилки під час добровільного надання першої допомоги такій особі або їхні зусилля виявилися неефективними (в тому числі за допомогою правового регулювання, відомого в світі як «закон доброго самаритянина»).

Висновки. При удосконаленні екстреної медичної допомоги на різних етапах її надання через призму медичної реформи в першу чергу необхідно звертати увагу на ситуативність та системність вирішення питань організації екстреної та невідкладної медичної допомоги. Першочергові завдання, які потрібно вирішувати при реформуванні системи, - це фінансові та кадрові. Солідарність у питаннях надання першої допомоги, захист медичних працівників, питання страхування їх здоров'я, підвищення соціального статусу - потребують першочергового вирішення. 


\section{СПИСОК ЛІТЕРАТУРИ}

1. Постанова Кабінету Міністрів України від 21 серпня 2019 р. № 764 [Електронний ресурс]. - Режим доступу : https://zakon.rada.gov.ua/laws/show/764-2019-\%D0\%BF.

2. Про схвалення Концепції розвитку системи екстреної медичної допомоги : розпорядження Кабінету Міністрів України від 22 травня 2019 р. № 383-р [Електронний ресурс]. - Режим доступу : https://zakon.rada.gov.ua/laws/ show/383-2019-\%D1\%80.

3. Надання першої допомоги без страху подальшого покарання [Електронний ресурс]. - Режим доступу : https://www.umj.com.ua/article/135276/nadannya-pershoyimedichnoyi-opomogi-bez-strahu-podalshogo-pokarannya.
4. Про аварійно-рятувальні служби : Закон України із змінами і доповненнями, внесеними Законами України від 21 грудня 2000 р. № 2171-ІІІ, від 19 січня 2006 р. № 3370-IV, від 24 вересня 2008 р. № 587-VI [Електронний ресурс]. - Режим доступу : https://dnaop.com/html/3442/ doc-zakon-ukrajini-pro-avarijno-ryatuvalyni-sluzhbi-.

5. Існуючі механізми співпраці органів державної влади з організаціями громадянського суспільства в контексті реалізації Національної стратегії сприяння розвитку громадянського суспільства в Україні 2016-2020 рр. - К. : Ваіте, 2016. - 280 c.

Отримано 30.03.20 